\title{
ISOLASI DAN KARAKTERISASI MOLEKULER MIKROBA ENDOFIT TANAMAN PEGAGAN (Centella asiatica L.) SEBAGAI PENGHASIL ANTIMIKROBA
}

\author{
Muh. Hidayat, Mufidah dan Herlina Rante \\ Fakultas Farmasi, Universitas Hasanuddin, Makassar
}

\section{Kata Kunci :}

Mikroba endofit, Paenibacillus alvei, Colletotrichum gloeosporioides, Centella asiatica $\mathrm{L}$

\begin{abstract}
ABSTRAK
Pegagan atau dikenal sebagai Centella asiatica L merupakan tumbuhan tropis di Indonesia yang sering digunakan sebagai obat traditional. Pegagan memiliki kandungan senyawa yang bermanfaat sebagai penyembuhan luka, antibakteri, antioksidan dan bahkan antikanker. Senyawa dengan karakteristik yang sama diperkirakan bisa dihasilkan oleh mikroba endofit yang ada pada pegagan. Penelitian ini bertujuan untuk mengisolasi dan melakukan karakterisasi molekuler isolate mikroba endofit pegangan yang memiliki potensi sebagai antimikroba. Ada enam isolat fungi endofit yang diisolasi, dua diantaranya adalah bakteri endofit dan empat lainnya adalah fungi endofit. Isolat bakteri endofit BEF1 dan fungi endofit FEF2 dipilih untuk dilanjutkan karakterisasi molekulernya setelah melihat hasil uji antagonis terhadap Staphylococcus aureus, Propionibacterium acnes, Pseudomonas aeruginosa, Streptococcus mutans, Salmonella typhosa, dan Candida Albicans. Isolat bakteri endofit BEF 1 menunjukkan zona hambatan terhadap Salmonella typhosa dan Propionibacterium acnes yaitu $8.1 \mathrm{~mm}$ dan $6.2 \mathrm{~mm}$. Zona hambatan isolat fungi endofit FEF2 terhadap Salmonella typhosa dan Propionibacterium acnes yaitu 9.3 $\mathrm{mm}$ dan $8.3 \mathrm{~mm}$. Isolat bakteri endofit BEF1 memiliki kekerabatan 100\% dengan Paenibacillus alvei, sedangkan isolate fungi endofit FEF2 memiliki kekerabatan 100\% dengan Colletotrichum gloeosporioides
\end{abstract}

\section{PENDAHULUAN}

Tanaman merupakan salah satu sumber untuk mendapatkan senyawa antimikroba yang didapatkan melalui ekstraksi tanaman. Tanaman dianggap menjadi sumber yang mudah didapatkan dan hampir $80 \%$ populasi di dunia menggunakannya sebagai bahan obat dan biasanya dipilih dari penggunaan tradisional (1). Produksi senyawa berkhasiat asal tanaman membutuhkan bahan baku yang sangat banyak, sehingga dibatasi oleh ketersediaan tanaman. Keberhasilan produk alam secara komersial bergantung pada ketersediaan tanaman. Dalam kasus lain, isolat senyawa yang berasal dari tanaman yang terancam punah atau yang sangat endemik akan berdampak buruk pada konservasi keanekaragaman hayati (2). Salah satu solusi dalam menangani masalah ini adalah penemuan mikroba yang berada di dalam jaringan tanaman yang dapat menghasilkan senyawa bioaktif yang memiliki karakteristik yang sama dengan tanaman inangnya, dikenal dengan mikroba endofit. Mikroba endofit merupakan organisme yang hidup berasosiasi dengan tanaman. Hidup di dalam interseluler tanaman, dalam jaringan seperti akar, batang, dan daun. Tetapi tidak menyebabkan gejala penyakit pada tanaman inang (3).

Dari sudut pandang komersial, fermentasi mikroba endofit relatif lebih mudah dan memungkinkan produksi senyawa biologis secara besarbesaran untuk memenuhi permintaan industri. Mikroba endofit memberi kesempatan untuk menemukan sejumlah besar senyawa baru dan menjadi sumber untuk produk alam (2). Mikroba endofit yang telah diisolasi dari beberapa tanaman menunjukkan potensi aktivitas biologi seperti antibakteri, antifungi, dan antitumor. Mikroba endofit memproduksi metabolit sekunder untuk melindungi tanaman dari serangan patogen. Beberapa penelitian mengenai mikroba endofit dari tanaman pegangan sebagai penghasil senyawa antimikroba telah dilakukan (4). Pegagan atau Centella asiatica L merupakan tanaman yang hampir ada di seluruh Asia. Centella asiatica L memiliki manfaat farmakologi yang banyak, digunakan sebagai penyembuhan luka, ganguan mental, antibakteri, antioksidan dan bahkan antikanker. Ekstrak etil asetat fungi endofit pegangan menunjukkan penghambatan pertumbuhan pada mikroba uji Klebsiella sp., Staphylococcus sp., Pseudomonas sp., Salmonella sp., Proteus sp., Shigella sp., Serratia sp. Nilai konsentrasi inhibisi minimum (MIC) untuk ekstrak berkisar antara $50,6 \mu \mathrm{g} / \mathrm{ml}$ sampai 274,6 $\mu \mathrm{g} / \mathrm{ml}(5)$.

\section{METODE PENELITIAN}

\section{Alat dan Bahan Penelitian}

Peralatan yang digunakan adalah alat-alat gelas, seperangkat alat Polimerase Chain Reaction (PCR), alat sentrifuge, autoklaf, cawan petri, enkas, inkubator, jangka sorong, laminar air flow (LAF), lemari pendingin, mikropipet, oven dan shaker.

Bahan yang digunakan yaitu air suling, aluminium foil, etanol 70\%, etil asetat, larutan NaOCI 5,25 \%, medium NA, medium PDA, mikroba uji (Candida albicans, Escherichia coli, Staphylococcus aureus, Streptococcus mutans, Salmonella thyposa, Pseudomonas aeruginosa, dan Propionibacterium acne), paper disk, dan sampel tanaman pegagan (Centella asiatica L.) 


\section{Isolasi Mikroba Endofit}

Tanaman pegagan dibersihkan menggunakan air mengalir. Diambil daun dan tangkai daun $2 \mathrm{~cm}$, dan dilakukan disinfeksi dengan etanol $70 \%$ selama 1 menit, dilanjutkan dengan Natrium Hipoklorit, 5,25\%. Dicuci kembali menggunakan etanol 70\% selama 30 detik, dilanjutkan dengan pembilasan menggunakan air steril selama 1 menit. Pembilasan dengan air steril dilakukan sebanyak dua kali. Air bilasan terakhir diambil sebanyak $1 \mathrm{~mL}$ dan disimpan pada cawan petri berisi media Nutrien Agar (NA) dan Potato Dekstrose Agar (PDA) kemudian sampel dikeringkan dengan menggunakan tissue steril selama satu menit. Sampel kemudian dipotong $1 \mathrm{~cm}$, dan tangkai daun dibelah menjadi dua bagian kemudian masing-masing sampel diletakkan dalam medium Nutrien Agar (NA) dan Potato Dekstrose Agar (PDA). dilakukan inkubasi $37^{\circ} \mathrm{C}$ selama 1 hari (6).

\section{Uji Antagonis}

Dilakukan penyiapan agar, strain mikroba endofit dibiakkan di cawan petri steril menggunakan medium sesuai, medium NA untuk bakteri dan medium PDA untuk fungi. Setelah inkubasi, agar sebesar $5 \mathrm{~mm}$ ditempatkan pada medium agar yang berisi mikroorganisme uji. Diameter zona hambat yang terbentuk diukur. Isolat yang memiliki aktivitas signifikan akan dilanjutkan pada perlakuan selanjutnya (3).

\section{Fermentasi dan Ekstraksi}

Isolat terpilih diinokulasikan ke dalam pada medium cair steril yang sesuai Nutrient broth (NB) untuk isolat bakteri dan Potato dekstrosa yeast (PDY) untuk isolat fungi. Labu diinkubasi selama 3 minggu pada shaker $150 \mathrm{rpm}$. Kemudian hasil fermentasi diekstraksi dengan menggunakan etil asetat (1:1) dan dievaporasi. Ekstrak di simpan pada suhu $4^{\circ} \mathrm{C}$ untuk digunakan lebih lanjut (7).

\section{Kurva Fermentasi Mikroba Endofit}

Isolat diinokulasikan ke dalam media fermentasi cair (Potato Dekstrosa Yeast) PDY untuk isolat fungi dan (Nutrien Broth) NB untuk isolate bakteri. Kemudian diinkubasi masingmasing medium tersebut pada suhu kamar $\left(25^{\circ} \mathrm{C}\right)$ selama 21 hari dalam kondisi terkocok, Setiap hari disampling masingmasing cairan fermentasi sebanyak $1 \mathrm{ml}$ dan disimpan dalam tabung eppendorf yang steril. Selanjutnya masing-masing cairan fermentasi tersebut disentrifus dengan kecepatan 6000 rpm pada suhu kamar selama sepuluh menit dan diambil filtratnya. Kemudian dilakukan uji aktivitas antimikroba dari masing-masing filtrat untuk mengetahui waktu inkubasi terbaik dari kedua jenis isolat endofit tersebut.

\section{Uji Aktivitas Antimikroba}

Pengujian ini menggunakan metode difusi yaitu sebanyak 20 $\mu \mathrm{l}$ dispersi mikroba uji dimasukkan ke dalam botol steril, lalu ditambahkan $20 \mathrm{ml}$ medium NA untuk bakteri uji dan PDA untuk jamur uji, dihomogenkan dan dituang ke dalam cawan petri, dibiarkan hingga memadat. Sebanyak $20 \mu$ l ekstrak dari masing-masing isolat yang dibuat konsentrasi sebesar 2500 ppm, 5000 ppm, 7500 ppm, dan 10000 ppm serta kontrol positif (kloramfenikol) dan kontrol negatif (etil asetat) dimasukkan ke dalam kertas cakram. Setelah semua pelarut menguap selanjutnya kertas cakram diletakkan pada permukaan medium yang telah berisi suspensi mikroba patogen, lalu diinkubasikan selama 24 jam pada suhu $37^{\circ} \mathrm{C}$ untuk mediuum NA dan tiga hari pada suhu $25^{\circ} \mathrm{C}$ untuk medium PDA (8).

\section{Ekstraksi DNA dan Amplifikasi PCR}

Ekstraksi DNA dilakukan untuk memisahkan genom DNA dari molekul-molekul lain dalam sel. Pada tahapan ini, ekstraksi DNA dilakukan dengan meggunakan kit Geneaid Presto $^{\mathrm{TM}}$ Mini gDNA Tissue yang merupakan kit ekstraksi DNA jaringan. Isolat diambil sebanyak $25 \mathrm{mg}$ dan di potongpotong kecil, ditempatkan dalam tabung eppendorf $1,5 \mathrm{~mL}$ lalu ditambahkan $180 \mu \mathrm{L}$ Buffer ATL. Ditambahkan $20 \mu \mathrm{L}$ Proteinase $K$ kemudian dihancurkan dengan mikropastel. Kemudian diinkubasi pada suhu $60^{\circ} \mathrm{C}$ selama 30 menit sehingga miselia jamur tersebut benar-benar hancur. Dilanjutkan dengan proses lysis, ditambahan GBT buffer pada sampel kemudian sampel diinkubasi selama 10 menit pada suhu $60^{\circ} \mathrm{C}$. Berikutnya dilakukan penambahan etanol absolut. DNA yang diperoleh kemudian dipindahkan ke dalam GD coloumn. Pada tahap ini dilakukan pencucian menggunakan wash buffer. Pada tahapan selanjutnya dilakukan proses rehidrasi DNA dengan menambahkan larutan pre-heated Elution buffer. Setelah proses rehidrasi selesai maka dihasilkan produk DNA.

Amplifikasi DNA berlangsung dengan tahap sebagai berikut. Tahap awal debaturasi $95^{\circ} \mathrm{C}$ selama 3 menit, denaturasi $95^{\circ} \mathrm{C}$ selama 15 detik, suhu anealling $50-60^{\circ} \mathrm{C}$ selama 15 detik dan extension $72^{\circ} \mathrm{C}$ selama 15 detik. Pada tahapan akhir proses PCR dilakukan Final Extension selama 3 menit pada suhu $75^{\circ} \mathrm{C}$ dengan 36 siklus. Dalam tahapan PCR digunakan primer Forward ITS5 dan Reverse ITS4 yang secara spesifik akan mengamplifikasi target sebagai berikut:Primer Forward : (5'GGAAGTAAAAGTCGTAACAAGG-3'), Primer Reverse : (5'TCCTCCGCTTATTGATATGC-3')

\section{Pohon Filogenetik}

Data sekuen dianalisis menggunakan ABI Auto Assambler dan sekuen yang telah dianalisis, dideterminasi menggunakan Auto Assambler. Kesamaan/similaritas dengan galur-galur referensi terdekat pada DNA Data Bank dapat diketahui dengan melakukan analisis Blast pada situs www.ncbi.nlm.nih.gov. Multiple Alignment dari sekuen dilakukan dengan program Clustal W. Untuk membangun pohon filogenetik digunakan metode neighbour-joining algorithm. Stabilitas pengelompokkan (robustness) diperhitungkan menggunakan bootstrap dengan 1000 kali ulangan.

\section{HASIL DAN PEMBAHASAN}

Isolat mikroba endofit yang tumbuh dipisahkan berdasarkan karakteristik morfologi, diperoleh 6 isolat mikroba endofit, 2 isolat merupakan bakteri endofit dan 4 merupakan fungi endofit. Uji antagonis menggunakan metode Agar block untuk mengetahui isolat yang memiliki aktivitas sebagai antimikroba. Mikroba patogen yang digunakan dalam pengujian ini adalah Bakteri gram negatif Eschericia coli Salmonella typhosa, Pseudomonas aeruginosa. Bakteri gram positif Streptococcus mutans, Staphylococcus aureus, Propionibacterium acnes serta fungi Candida albicans. Berdasarkan hasil uji antagonis (Tabel 2) dari enam isolat mikroba endofit tersebut diperoleh data bahwa isolat BEF1 memiliki zona hambatan yang besar pada Propionibacterium acnesdan $S$. typhosa dibandingkan isolat yang lain. Semua isolat menunjukkan daya hambat terhadap Propionibacterium acnes. Hanya isolate BEF1, FEF2, dan FEF4 yang menunjukkan zona hambatan pada Candida albicans. Oleh karena itu, isolat BEF1 dan FEF2 dipilih untuk dilanjutkan ke tahap identifikasi molekuler dan produksi metabolit sekundernya.

Isolat yang memiliki aktivitas yang lebih besar yaitu BEF1 dan FEF2 kemudian dilakukan fermentasi untuk mengetahui waktu optimum dihasilkannya metabolit sekunder. Metabolit sekunder dihasilkan pada fase stasioner. Pada fase ini sel menjadi tua, laju pembiakan berkurang dan beberapa sel mati karena menyusutnya nutrien dalam media. Akan tetapi metabolisme pada fase ini masih terus berlangsung, dapat 


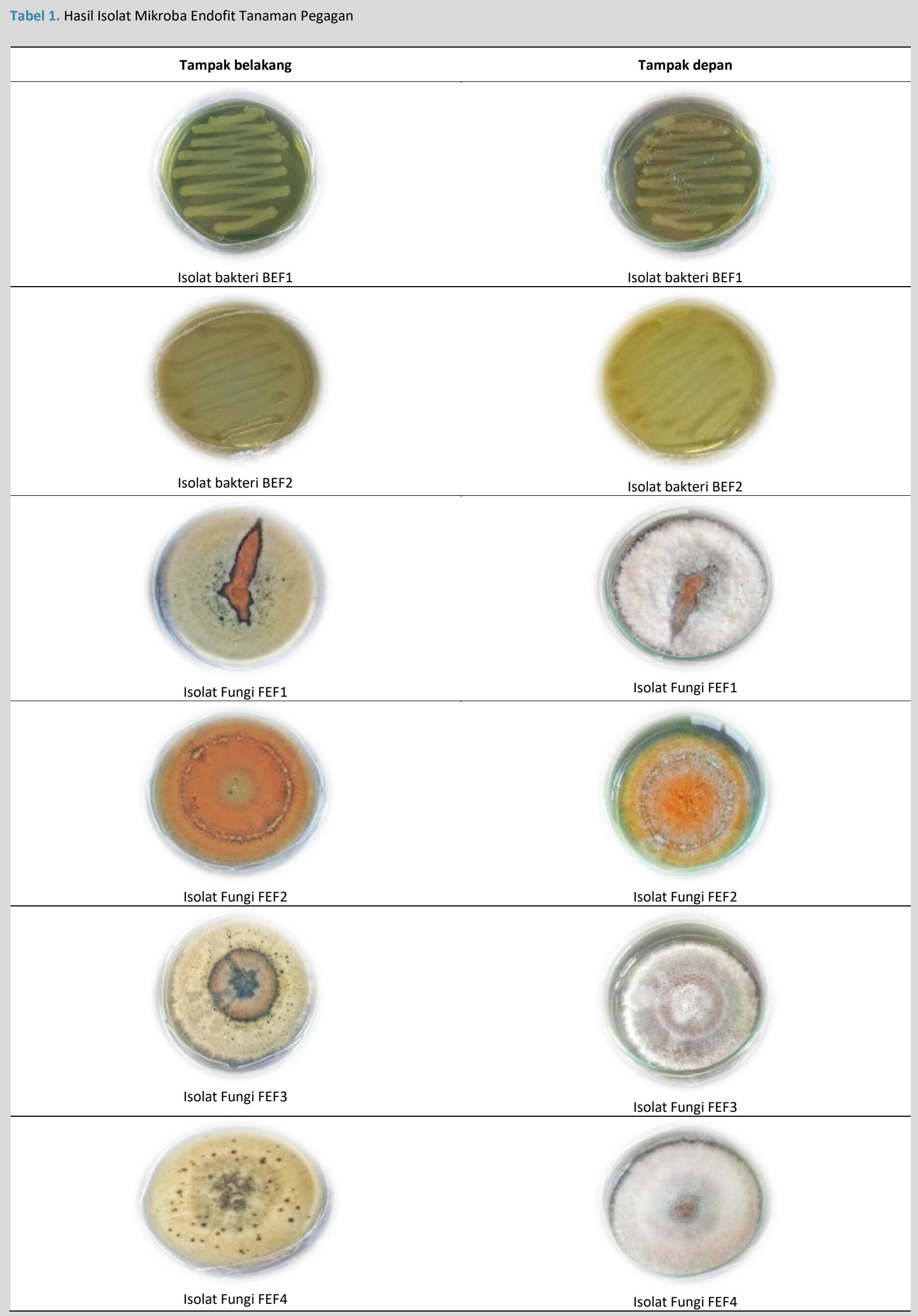

terlihat pada melimpahnya produk metabolisme yang cenderung menumpuk. Metabolit sekunder pada umumnya terbentuk pada fase ini yaitu pada saat populasi sel tetap (jumlah sel tumbuh dan sel mati sama). Sintesis metabolit sekunder dimulai pada saat mulai habisnya beberapa komponen utama nutrien pada media pertumbuhan. Waktu optimal fermentasi pada isolat BEF1 yaitu pada hari ke 17 dan isolat FEF2 yaitu pada hari ke 14, dengan melihat zona hambat pada kedua bakteri uji Salmonella typhosa dan Propionibacterium acnes. 
Tabel 2. Hasil Uji Antagonis Isolat Mikroba Endofit.

\begin{tabular}{lcccccccc}
\hline \multirow{8}{*}{ Isolat } & S. & $P$. & $P$. & $S$. & S. & E. & $\begin{array}{c}\text { C. } \\
\end{array}$ \\
\cline { 2 - 8 } & aureus & acne & aeruginosa & mutans & typhosa & coli & albicans \\
\hline BEF1 & + & + & + & + & + & - & + \\
BEF2 & - & + & + & + & + & - & - \\
FEF1 & + & + & + & + & - & - & - \\
FEF2 & + & + & + & + & + & - & + \\
FEF3 & + & + & + & + & + & - & - \\
FEF4 & + & + & - & + & - & - & + \\
\hline Keterangan: & \\
terbentuk zona hambatan (+) dan tidak membentuk zona hambatan (-)
\end{tabular}

Ekstrak yang diperoleh dari isolat BEF1 dan FEF2 diuji aktivitas antimikrobanya terhadap mikroba patogen Propionibacterium acnes dan Salmonella typhosa menggunakan metode difusi agar dan diukur diameter zona hambatan yang terbentuk. Berdasarkan data yang diperoleh menunjukkan bahwa senyawa metabolit yang dihasilkan oleh isolat fungi endofit FEF2 dan bakteri endofit BEF1 memiliki aktivitas antimikroba. Hal ini dapat dilihat melalui zona hambat yang dihasilkan. Pada konsentrasi $10.000 \mathrm{ppm}$ atau $1 \%$ isolat fungi endofit FEF2 menunjukkan zona hambat 9.3 $\mathrm{mm}$ terhadap Salmonella typhosa, dan $8.3 \mathrm{~mm}$ terhadap Propionibacterium acnes. Isolat bakteri endofit BEF1 pada konsentrasi $10.000 \mathrm{ppm}$ atau $1 \%$ menunjukkan zona hambat $8.1 \mathrm{~mm}$ terhadap bakteri Salmonella typhosa, dan $6.2 \mathrm{~mm}$ terhadap Propionibacterium acnes.

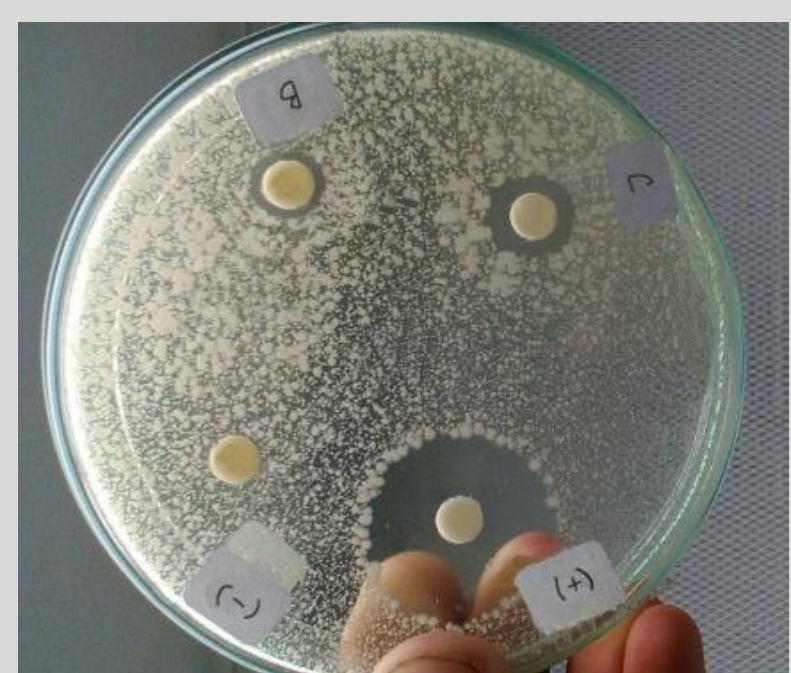

Gambar 1. Hasil Uji Aktivitas Isolat Mikroba Endofit Terhadap Propionibacterium acnes, B (Ekstrak metabolit sekunder isolat BEF1, konsentrasi $10.000 \mathrm{ppm}$ ), J (Ekstrak metabolit sekunder isolat FEF2, konsentrasi $10.000 \mathrm{ppm}),(-)$ kontrol negatif etil asetat, (+) kontrol positif kloramfenikol $30 \mathrm{ppm}$.

Hasil amplifikasi DNA dari kedua isolat endofit tersebut kemudian divisualisasi dengan elektroforesis. Terlihat bahwa DNA dari isolat fungi endofit FEF2 teramplifikasi memiliki panjang 579 bp dan untuk isolat bakteri endofit BEF1 913 bp. Hasil PCR disekuensing untuk mendapatkan sekuen basa berupa format ab1. Sekuen diedit pada trace editor MEGA 6.0 untuk memilih bagian sekuen yang akan digunakan untuk melakukan BLAST (Basic Local Alignment Search Tool) pada https://blast.ncbi.nlm.nih.gov/Blast.cgi, Setelah BLAST dilakukan maka akan didapatkan kumpulan data sekuen dari spesies dengan yang memiliki kemiripan urutan basa pada DNAnya. Dibuat pohon filogenetik menggunakan perangkat lunak MEGA 6.06 dengan metode neighbor joining (NJ). Kelebihan metode $N$ J dianggap cepat dibandingkan metode yang lainnya, lebih praktis untuk menganalisis kumpulan data yang besar (ratusan atau ribuan taksa) dan untuk bootstrap atau tujuan analisis lainnya yang dapat dihitung secara komputasi (9). Hasil BLAST dan pohon filogenetik menunjukkan bahwa BEF1 memiliki kekerabatan 100\% dengan Paenibacillus alvei, sedangkan FEF2 memiliki kekerabatan $100 \%$ dengan Colletotrichum gloeosporioides.

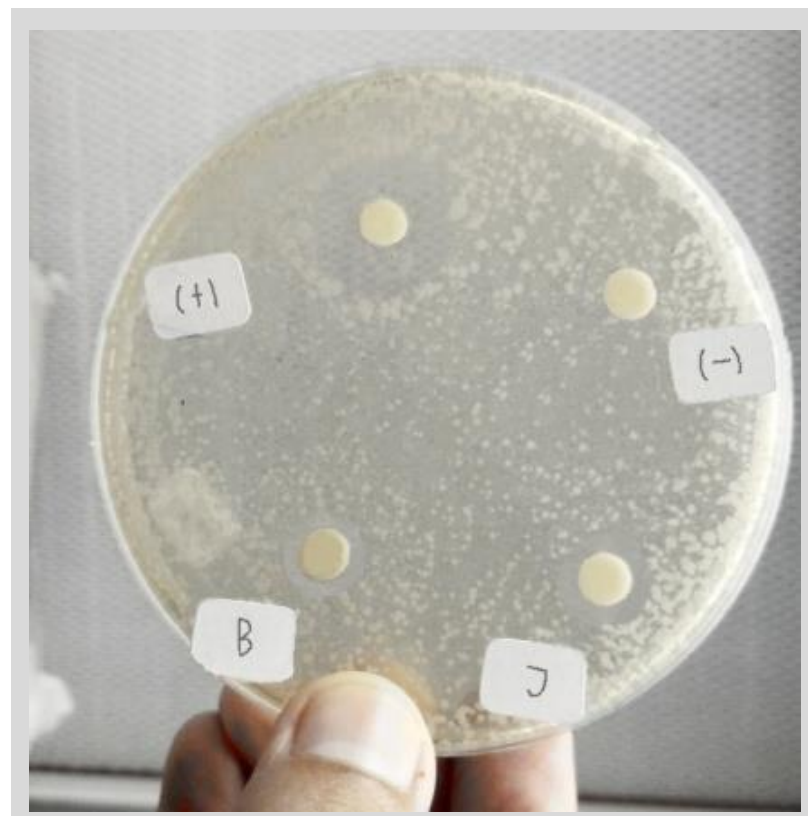

Gambar 2. Hasil Uji Aktivitas Isolat Mikroba Endofit Terhadap Salmonella thyposa, B (Ekstrak metabolit sekunder isolat BEF1, konsentrasi 10.000 ppm), J (Ekstrak metabolit sekunder isolat FEF2, konsentrasi $10.000 \mathrm{ppm}),(-)$ kontrol negatif etil asetat, (+) kontrol positif kloramfenikol $30 \mathrm{ppm}$.
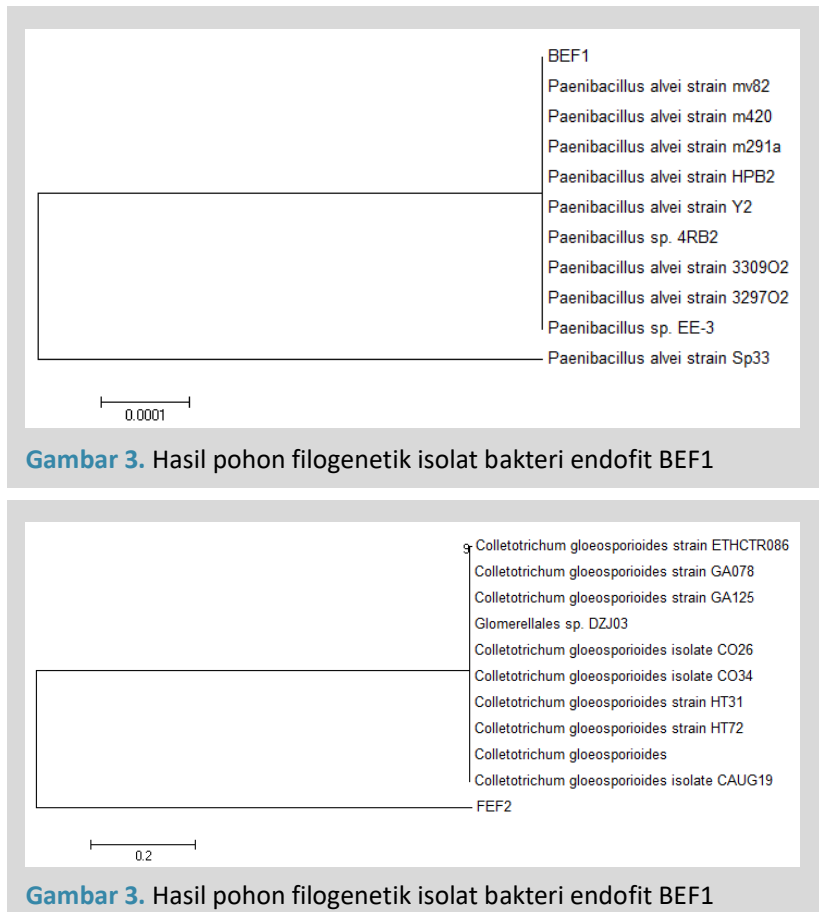

\section{KESIMPULAN}

Diperoleh 2 isolat bakteri endofit dan 4 isolat fungi endofit dari pegangan. Hasil skrining fotokimia menunjukkan bahwa aktivitas terbesar pada isolat bakteri endofit BEF1 dan fungi endofit FEF2. Isolat bakteri endofit BEF1 memiliki kekerabatan 100\% dengan Paenibacillus alvei, sedangkan isolat fungi endofit FEF2 memiliki kekerabatan 100\% dengan Colletotrichum gloeosporioides. 


\section{DAFTAR PUSTAKA}

1. Dash, Faruquee, Biswas, Alam, Sisir, Prodhan. Antibacterial and Antifungal Activities of Several Extracts of Centella asiatica L. against Some Human Pathogenic Microbes. Life Sciences and Medicine Research. 2011:1-5

2. Alvin, Miller, K.I., Neilan, B.A. Exploring the potential of endophytes from antimycobacterial compounds. Microbiol. Res. 2014; 169:483-495

3. Ramos, Silva, Correia, Araujo, Coelho. Enhopityc microorganisms from bauhinia monandra leaves: isolation, antimicrobial activities and interaction with galactose-spesific lectin BmmolL. African journal of microbiological research, 2016; vol 10(17): 600-607

4. Rafat, Philip, Muniandy. A Novel Source of Bioactive Compounds: Endophytic Bacteria Isolated from Centella asiatica. Journal of Pure and Applied Microbiology. 2012; Vol 6.
5. Prabakaran, Nameirakpam Nirjanta Devi, and W. Femina. Antibiogram pattern of enhopityc fungi isolated from medical plant centella asiatica. Journal of pharmacy research, 2012; 5: 205-207

6. Jasim, Aswathy Agnes Joseph, Jimtha John, Jyothis Mathew, and Radhakrishnan. Isolation and Characterization of Plant Growth Promoting Endophytic Bacteria from The Rhizome of Zingiber officinale. Biotech, 2014; 4:197-204

7. Senthilmurugan VG, Sekar R, Kuru S, Balamurugan S. Phytochemical screening, enzyme and antibacterial activity analysis of endophytic fung Botrytis sp. isolated from Ficus benghalensis (L.). Int J Pharm Res Biol Sci, 2013; 2(4): 264-273

8. Rante, H., Taebe, B., Intan, S. Isolasi Fungi Endofit penghasil Senyawa Antimikroba dari daun Cabai Katokkon (Capsicum annum L var. chinensis) dan Profil KLT Bioautografi. Majalah Farmasi dan Farmakologi, 2013; Vol. 17, No. 2: hlm 39-46 (ISSN 1410-7031)

9. Mihaescu R, Levy D, Pachter L. Why Neighbor-Joining Works. Algorithmica 2009; Vol 54, issue 1, pp 1-24. 